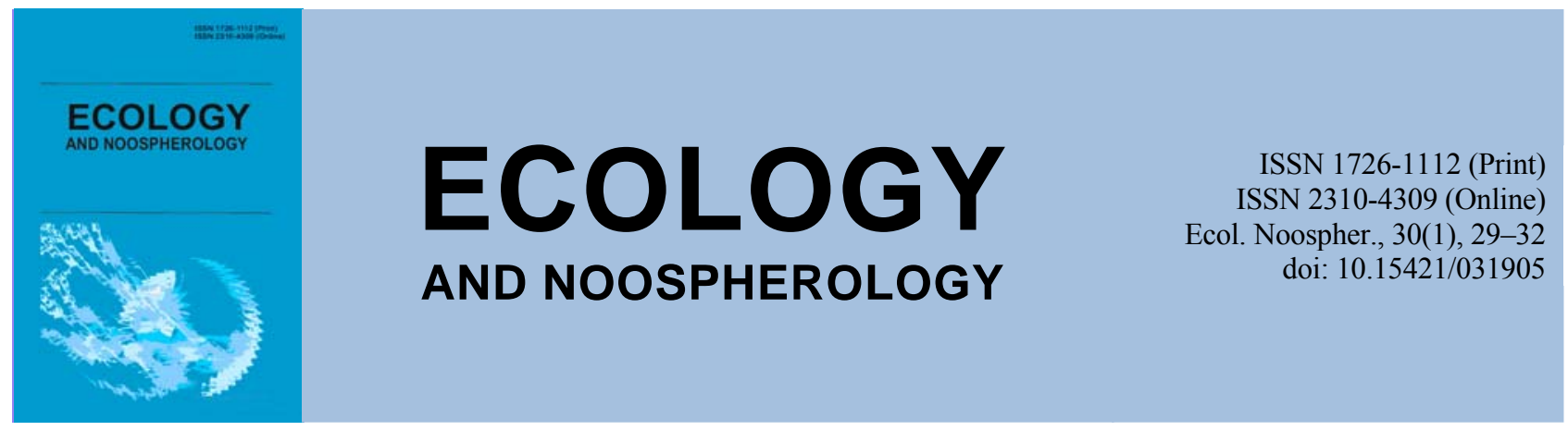

\title{
Free DNA in environment and its use in systematics of macrofungi
}

\author{
V. M. Pomohaibo, N. A. Vlasenko, L. D. Orlova \\ Poltava V. G. Korolenko National Pedagogical University, Poltava, Ukraine
}

Article info

Received 11.02.2019

Received in revised form

19.02.2019

Accepted 27.02.2019

Poltava V. G. Korolenko National Pedagogical

University, Ostrogradsky Str.,2,

Poltava, 36000, Ukraine.

Tel.: +38-050-833-81-33

E-mail:vmpom@ukr.net

\begin{abstract}
Pomohaibo, V. M., Vlasenko, N. A., Orlova, L. D. (2019). Free DNA in environment and its use in systematics of macrofungi. Ecology and Noospherology, 30(1), 29-32. doi:10.15421/031905
\end{abstract}

On the basis of the review of numerous scientific publications, in our article there is compared the effectiveness of various study methods of macrofungi groups, the species diversity of which remains largely unknown. Macrofungi form the visible fruit body. They are found in most environmental conditions, but are most common in forest ecosystems, where they are reducers. Macrofungi belong to the Ascomycota and Basidiomycota types within the Dikarya subkingdom and are divided into saprotroph, parasitic and mycorrhizal fungi. Saprotroph species play a main part in the decomposition of organic matter of soil, fallen leaves and dead wood. Parasitic macrofungi cause a number of diseases of other mushrooms, plants and animals (mostly invertebrates). Mycorrhizal fungi form a symbiotic system with plant roots, which is useful for both partners. There are known over 90000 species of macrofungi that is about $60 \%$ of the number of all described fungal species in the present (Deacon, 2006; Orgiazzi et al., 2016). Macrofungi are considered to be studied in the best way, but their species diversity remains largely unknown. For example, in the course of over last 60 years more 56000 species of macrofungi have been identified in Australasia, China, and Japan, of which 35000 species, or $62 \%$, are unknown (Mueller et al., 2007). At the same time, in China and Japan the part of new macrofungal species was $37 \%$, and in Australasia - $72 \%$. To determine the diversity of macrofungi three methods can be used: a collections of fruit bodies, mycelium cultivation on the agar substrate and free fungal DNA in the environment. The study of collections are used most commonly. However, in the case when mushrooms have large fruit bodies, but they are short-lived, this method is not always able to detect them and attach them to the collection. For other two methods, the presence of fruit bodies is not obligatory. But the mycelium cultivation method also has a drawback, since not all mycorrhizal and parasitic mushrooms can be cultivated in the laboratory because they can't exist outside the symbiosis with the roots of living plants or outside the host's body, respectively. Altogether together both collection studying and mycelium cultivation methods can find a significant majority of the environmental fungal taxons, which form fruit bodies. However, they can not reflect the relative prevalence of species. The method of molecular genetic analysis of the environmental DNA (eDNA) has the greatest advantages of other two, since it is also suitable for the discovery of such taxonomic units. This method has allowed to identify new branches, including ancient branched fungal lines, such as Cryptomycota or Archaeorhizomycetes. True, sometimes the method of eDNA analysis does not find taxonomic units, which are detected by the collection of fruit bodies or by mycelium cultivating. But this may have been due to sample incompleteness or to errors in the complex process of eDNA analysis. Since in these analysis there are used fragments of DNA or RNA only a few hundred bases long, this method is not able to detect a number of biological indices that can be obtained by examining of a fungal collection or culture. Thus to obtain most complete information about macrofungal community structure as well as their genomic, physiological and ecological properties it is necessary to use all three methods.

Keywords: macrofungi; environmental DNA (eDNA); collection of fruit bodies; cultivation; molecular genetic research

\section{Вільна ДНК у навколишньому середовищі та її використання в систематиці макрогрибів}

\author{
В. М. Помогайбо, Н. О. Власенко, Л. Д. Орлова
}

Полтавський національний педагогічний університет ім. В. Г. Короленка, Полтава, Украӥна 
Подано огляд наукових публікацій, який висвітлює результати порівняння ефективності різних методів дослідження угруповань макрогрибів, видова різноманітність яких залишається переважно невідомою. Для ії визначення існує три засоби: колекція плодових тіл, культивування міцелію та молекулярно-генетичний аналіз вільною ДНК навколишнього середовища (ДНКнс). Нині найбільш поширеним залишається обстеження колекцій. Однак у випадку коли гриби мають хоча й досить великі плодові тіла, але існуючі короткочасно, цей метод не завжди здатний їх виявити і прилучити до колекції. Метод культивування, у свою чергу, обмежений тим, що частина мікоризних і особливо паразитуючих грибів не здатна існувати на штучному субстраті. Загалом методи вивчення колекції та культури міцелію разом здатні показати значну більшість наявних у навколишньому середовищі таксонів грибів, які утворюють плодові тіла. Однак вони не можуть відобразити відносну поширеність видів. Усіх цих недоліків позбавлений лише молекулярно-генетичний аналіз ДНКнс, хоча поки-що він має свої специфічні недоліки, бо не дає повної біологічної інформації про виявлені нові види і не виявляє рідкісні види, ДНК яких може бути відсутня в зразках із навколишнього середовища. Таким чином, у мікологічних дослідженнях не варто надавати перевагу певному одному методу. Хоча найбільш результативним $є$ метод аналізу ДНКнс, але для одержання найбільш повної інформації про структуру угруповань грибів з плодовими тілами, а також про їх геномні, фізіологічні та екологічні властивості необхідно користуватися всіма трьома методами.

Ключові слова: макрогриби; ДНК навколишнього середовища (ДНКнс); колекція плодових тіл; культивування; молекулярногенетичний аналіз

\section{Вступ}

Макрогриби є групою грибів, які формують видиме плодове тіло. Вони виявлені в більшості природних умов існування, але найпоширеніші в лісових екосистемах, де виконують роль редуцентів. Макрогриби можуть бути сапротрофними, паразитуючими або мікоризними. Сапротрофні види беруть головну участь у розкладанні органічної речовини грунту, опалого листя та мертвої деревини. Паразитуючі макрогриби спричинюють ряд захворювань інших грибів, рослин і тварин (переважно безхребетних). Мікоризні гриби формують симбіотичну систему 3 коренями рослин, яка сприятлива для обох партнерів. Макрогриби належать до типів Ascomycota та Basidiomycota у складі підцарства Dikarya. Аскоміцети нараховують понад 60 тис. видів і складають найчисленнішу групу грибів. Їх плодове тіло має вигляд чашки або диска. Базидіоміцетів описано понад 30 тис. видів, а їх плодове тіло складається із шапки та ніжки. Таким чином, макрогрибів відомо понад 90 тис. видів, що становить близько $60 \%$ від кількості описаних на цей час видів усіх грибів (Deacon, 2006; Orgiazzi et al., 2016).

Хоча макрогриби найкраще вивчені, їх видова різноманітність залишається переважно невідомою. Наприклад, лише на території Австралазії, Китаю та Японії за період понад 60 останніх років було виявлено понад 56 тис. видів макрогрибів, із яких 35 тис. невідомі, що становить понад $62 \%$. При цьому в Китаї та Японії доля нових видів макрогрибів склала $37 \%$, а в Австралазії - $72 \%$ (Mueller et al., 2007).

\section{Порівняльна характеристика методів дослідження макрогрибів}

Для визначення різноманітності макрогрибів мікологи можуть користуватися трьома засобами: колекцією плодових тіл, культивуванням міцелію та вільною ДНК грибів у навколишньому середовищі. Проте вони найчастіше надають перевагу вивченню колекцій (Brown et al., 2006; O'Hanlon et al., 2012; Angelini et al., 2016). Однак у випадку коли гриби мають хоча й досить великі плодові тіла, але існуючі короткочасно, цей метод не завжди здатний їх виявити і прилучити до колекції. Для інших двох методів наявність плодових тіл не $є$ необхідною умовою. Серед них найбільші переваги має метод молекулярно-генетичного аналізу ДНК навколишнього середовища (ДНКнс), коротка характеристика якого подана нами в попередній публікації (Pomohaybo, Makarenko, 2017).

Сапротрофні гриби, існуючі на мертвій деревині або опалому листі, здатні утворити міцелій на агаровому субстраті. Однак не всі мікоризні та паразитуючі гриби можуть бути культивовані в лабораторних умовах через нездатність існувати поза симбіозом 3 коренями живих рослин або поза організмом живителя відповідно (Allen et al., 2003; Deacon, 2006). Лише аналіз ДНКнс придатний для виявлення саме таких таксономічних одиниць (Arnold et al., 2007; Lindner et al., 2011). Саме цей метод дозволив ідентифікувати нові гілки, включаючи давні розгалужені лінії грибів, такі як Cryptomycota або Archaeorhizomycetes (Jones et al., 2011; Rosling et al., 2011). Правда, іноді метод аналізу ДНКнс не виявляє таксономічні одиниці, визначені за колекцією плодових тіл або при культивуванні (Porter et al., 2008; Higgins et al., 2011; Langarica-Fuentes et al., 2014). Але така невідповідність могла статися через неповноту відібраних зразків (Allmér et al., 2006; Lindner et al., 2011) або похибки у процесі вилучення ДНК чи здійснення полімеразної ланцюгової реакції (Martin-Laurent et al., 2001; Tedersoo et al., 2010; Lindahl et al., 2013).

Оскільки для аналізу ДНКнс використовують фрагменти ДНК або РНК довжиною всього кілька сотень основ, цей метод не здатен виявити ряд біологічних показників, які можна одержати за допомогою обстеження колекції чи культивування. Таким чином, кожен метод дослідження різноманітності грибів має свої переваги та недоліки. На підставі результатів низки досліджень 3 використанням певних пар цих методів була отримана важлива інформація для розробки ефективних стратегій дослідження різноманітності грибів (Johannesson et al., 1999; Porter et al., 2008; Fischer et al., 2012; Hiscox et al., 2015).

На цей час $\epsilon$ також кілька експериментальних порівнянь усіх трьох методів визначення біорізноманіття грибів (Allmér et al., 2006; Lindner et al., 2011; Shirouzu et al., 2016). За результатами першого 3 них на семирічній мертвій деревині ялини європейської було виявлено загалом 58 видів грибів, із яких 31 вид був ідентифікований на основі вивчення колекції плодових тіл, 27 за допомогою культивування міцелію та 5 видів на підставі аналізу грибної ДНК безпосередньо із зразків деревини (Allmér et al., 2006). При цьому 1 вид був визначений всіма трьома методами. I3 5 видів, ідентифікованих аналізом ДНК із зразків деревини, 4 види були також визначені на основі вивчення міцеліальної культури і 1 вид - лише за аналізом ДНК. Загалом методи вивчення колекції та культури міцелію разом здатні показати значну більшість наявних у навколишньому середовищі таксонів грибів, які утворюють плодові тіла. Однак вони не можуть відображати відносну поширеність видів. Цього недоліку позбавлений метод аналізу ДНК грибів, яка була виділена із зразків деревини, хоча він може пропустити більшість видів, особливо рідкісних.

Варто наголосити, що в цитованій роботі презентовані дані, які є статистично недостовірними через недостатню кількість повторень, тому значно більше довіри викликають дві інші публікації щодо порівняння трьох відомих методів дослідження біорізноманіття грибів, в 
яких показано статистичну достовірність експериментальних результатів. В одній iз них на шестирічній мертвій деревині ялини європейської показано значні переваги методу аналізу ДНК у визначенні біорізноманіття грибів, які формують плодові тіла (Lindner et al., 2011). На основі вивчення колекції плодових тіл було виявлено 18 видів (базидіоміцети), а за допомогою культивування міцелію - 23 види (7 - базидіоміцети, 7 аскоміцети, 3 - зигоміцети та 6 - невідомі види). Аналіз ДНК із зразків деревини виявив 72 таксони, із яких базидіоміцетів - 16 видів і 4 таксони родового рівня, аскоміцетів - 30 видів і 16 таксонів родового рівня, гломероміцетів -3 таксони невідомого рівня та 3 невідомі таксони. У результатах усіх трьох методів зустрічаються лише 3 види. Вивчення колекції плодових тіл виявило 13 видів грибів, які не фігурують у даних інших двох методів, але не виявило невідомі види. Культивування міцелію показало 9 таксономічних одиниць, які не зустрічаються в результатах інших двох методів, та 6 невідомих видів. Аналіз ДНК із зразків мертвої деревини виявив 66 таксономічних одиниць, яких бракує за даними інших двох методів, із яких 3 - невідомі таксони.

У справі порівняння різних методів визначення біорізноманіття грибів 3 видимими плодовими тілами цікавим $\epsilon$ також дослідження японських мікологів, які за експериментальну модель узяли деревинні редуценти класу Dacrymycetes (підтип Agaricomycotina, тип Basidiomycota) (Shirouzu et al., 2016). Цей клас $\epsilon$ монофілетичною групою, що містить близько 110 видів грибів бурої гнилизни. Він придатний для вивчення екології та еволюції базидіоміцетів, що руйнують деревину. Три причини спонукали дослідників вибрати саме ці гриби: 1) у них $є$ видимі плодові тіла і значна частина їх видової різноманітності була виявлена на основі дослідження цих тіл, 2) вони піддаються культивуванню на агаровому субстраті, утворюючи легко помітні колонії жовтого або помаранчевого кольору, 3) вони мають достатню кількість інформативних послідовностей ДНК, придатних для їх молекулярної ідентифікації. Дослідження здійснені у лісовому масиві на повалених стовбурах червоної японської сосни. За допомогою аналізу ДНКнс було виявлено 24 види дакриміцетів, із яких 7 невідомі. Колекція плодових тіл показала 20 видів, у тому числі 3 невідомі. На основі культивування міцелію визначено всього 13 видів, із яких 3 невідомі. ДНКнс і колекція показали по 14 видів, які не були виявлені іншими методами. Культивування дало тільки 8 таких видів.

\section{Висновки}

Для визначення різноманітності макрогрибів можна користуватися трьома засобами - колекцією плодових тіл, культивуванням міцелію та ДНКнс грибів. На основі аналізу результатів порівняння цих засобів можна констатувати, що в мікологічних дослідженнях не варто надавати перевагу певному одному методу. Хоча найбільш результативним $\epsilon$ метод аналізу ДНКнс, але для одержання найбільш повної інформації про структуру угруповань грибів 3 плодовими тілами, а також про їх геномні, фізіологічні та екологічні властивості необхідно користуватися всіма трьома методами.

\section{References}

Allen, T. R., Millar, T., Berch, S. M. and Berbee M. L. (2003) Culturing and direct DNA extraction find different fungi from the same ericoid mycorrhizal roots. New Phytol., 160(1), 255-272. DOI: 10.1046/j.1469-8137.2003.00885.x.

Allmér, J., Vasiliauskas, R., Ihrmark, K., Stenlid, J. and Dahlberg, A. (2006). Wood-inhabiting fungal communities in woody debris of Norway spruce (Picea abies (L.) Karst.), as reflected by sporocarps, mycelial isolations and T-RFLP identification.
FEMS Microbiol. Ecol., 55(1), 57-67. DOI: 10.1111/j.15746941.2005.00010.x.

Angelini, P., Compagno, R., Arcangeli, A., Bistocchi, G., Gargano, M. L., Venanzoni, R. and Venturella, G. (2016). Macrofungal diversity and ecology in two Mediterranean forest ecosystems. Plant Biosystems, 150(3), 540-549. DOI: 10.1080/11263504.2014.987844.

Arnold, A. E., Henk, D. A., Eells, R. L., Lutzoni, F. and Vilgalys, R. (2007). Diversity and phylogenetic affinities of foliar fungal endophytes in loblolly pine inferred by culturing and environmental PCR. Mycologia, 99(2), 185-206.

Brown, N., Bhagwat, Sh. and Watkinson, S. (2006). Macrofungal diversity in fragmented and disturbed forests of the Western Ghats of India. J. Appl. Ecol., 43(1), 11-17. DOI: 10.1111/j.1365-2664.2005.01107.x.

Deacon, J. (2006). Fungal biology. 4th ed. Oxford, WileyBlackwell, VII +372 pp.

Fischer, A. L., Moncalvo, J.-M., Klironomos, J. N. and Malcolm, J. R. (2012). Fruiting body and molecular rDNA sampling of fungi in woody debris from logged and unlogged boreal forests in northeastern Ontario. Ecoscience, 19(4), 374-390. DOI: 10.2980/19-4-3513.

Higgins, K. L., Coley, P. D., Kursar, T. A. and Arnold, A. E. (2011). Culturing and direct PCR suggest prevalent host generalism among diverse fungal endophytes of tropical forest grasses. Mycologia, 103(2), 247-260. DOI: 10.3852/09-158.

Hiscox, J., Savoury, M., Müller, C. T., Lindahl, B. D., Rogers, H. J. and Boddy, L. (2015). Priority effects during fungal community establishment in beech wood. ISME J., 9(10), 2246-2260. DOI: 10.1038/ismej.2015.38.

Johannesson, H. and Stenlid, J. (1999). Molecular identification of wood-inhabiting fungi in an unmanaged Picea abies forest in Sweden. For. Ecol. Manage., 115(2-3), 203-211.

Jones, M. D. M., Forn, I., Gadelha, C., Egan, M. J., Bass, D., Massana, R. and Richards, T. A. (2011). Discovery of novel intermediate forms redefines the fungal tree of life. Nature, 474(7350), 200-205. DOI: 10.1038/nature09984.

Langarica-Fuentes, A., Handley, P. S., Houlden, A., Fox, G. and Robson, G. D. (2014). An investigation of the biodiversity of thermophilic and thermotolerant fungal species in composts using culture-based and molecular techniques. Fungal Ecol., 11, 132-144. DOI: 10.1016/j.funeco.2014.05.007.

Lindahl, B. D., Nilsson, R. H., Tedersoo, L., Abarenkov, K., Carlsen, T., Kjøller, R., Kõljalg, U., Pennanen, T., Rosendahl, S., Stenlid, J. and Kauserud, H. (2013). Fungal community analysis by high-throughput sequencing of amplified markers - a user's guide. New Phytol., 199(1), 288-299. DOI: 10.1111/nph.12243.

Lindner, D. L., Vasaitis, R., Kubartová, A., Allmer, J., Johannesson, H., Banik, M. T. and Stenlid, J. (2011). Initial fungal colonizer affects mass loss and fungal community development in Picea abies logs 6yr after inoculation. Fungal Ecol., 4(6), 449-460. DOI: 10.1016/j.funeco.2011.07.001.

Martin-Laurent, F., Philippot, L., Hallet, S., Chaussod, R., Germon, J. C., Soulas, G. and Catroux, J. DNA extraction from soils: old bias for new microbial diversity analysis methods. Appl. Environ. Microb., 67(5), 2354-2359. DOI: 10.1128/AEM.67.5.2354-2359.2001.

Mueller, G. M., Schmit, J. P., Leacock, P. R., Buyck, B., Cifuentes, J., Desjardin, D. E., Halling, R. E., Hjortstam, K., Iturriaga, T., Larsson, K.-H., Lodge, D. J., May, T. W., Minter, D., Rajchenberg, M., Redhead, S. A., Ryvarden, L., Trappe, J. M., Watling, R., Wu, Q. (2007). Global diversity and distribution of macrofungi. Biodivers. Conserv., 16(1), 37-48. DOI: 10.1007/s10531-006-9108-8.

O'Hanlon, R. and Harrington, Th. J. (2012). Macrofungal diversity and ecology in four Irish forest types. Fungal Ecology, 5(5), 499-508. DOI:10.1016/j.funeco.2011.12.008.

Orgiazzi, A., Bardgett, R. D., Barrios, E., Behan-Pelletier, V., Briones, M. J. I., Chotte, J-L., De Deyn, G. B., Eggleton, P., Fierer, N., Fraser, T., Hedlund, K., Jeffery, S., Johnson, N. C., Jones, A., Kandeler, E., Kaneko, N., Lavelle, P., Lemanceau, P., 
Miko, L., Montanarella, L., Moreira, F. M. S., Ramirez, K. S., Scheu, S., Singh, B. K., Six, J., van der Putten, W. H., Wall, D. H. (Eds.) (2016). Global soil biodiversity atlas. Luxembourg, European Commission, Publications Office of the European Union, $176 \mathrm{pp}$.

Pomohaybo, V. M., Makarenko, Ya. M. (2017). Environmental DNA as a tool for ecological monitoring of fungal communities. Ukr. Bot. J., 74(5), 442-448. DOI: 10.15407/ukrbotj74.05.442.

Porter, T. M., Skillman, J. E. and Moncalvo, J.-M. (2008). Fruiting body and soil rDNA sampling detects complementary assemblage of Agaricomycotina (Basidiomycota, Fungi) in a hemlock-dominated forest plot in southern Ontario. Mol. Ecol., 17(13), 3037-3050. DOI: 10.1111/j.1365294X.2008.03813.x.
Rosling, A., Cox, F., Cruz-Martinez, K., Ihrmark, K., Grelet, G.-A., Lindahl, B. D., Menkis, A. and James, T. Y. (2011). Archaeorhizomycetes: unearthing an ancient class of ubiquitous soil fungi. Science, 333(6044), 876-879. DOI: 10.1126/science. 1206958.

Shirouzu, T., Uno, K., Hosaka, K. and Hosoya, T. (2016). Earlydiverging wood-decaying fungi detected using three complementary sampling methods. Mol. Phylogen. Evol., 98, 11-20. DOI: 10.1016/j.ympev.2016.01.015.

Tedersoo, L., Nilsson, R. H., Abarenkov, K., Jairus, T., Sadam, A., Saar, I., Bahram, M., Bechem, E., Chuyong, G. and Kõljalg, U. (2010). Pyrosequencing and Sanger sequencing of tropical mycorrhizal fungi provide similar results but reveal substantial methodological biases. New Phytol., 188(1), 291-301. DOI: 10.1111/j.1469-8137.2010.03373.x. 